www.jmscr.igmpublication.org

Impact Factor (SJIF): 6.379

Index Copernicus Value: 71.58

ISSN (e)-2347-176x ISSN (p) 2455-0450

crossref DOI: _https://dx.doi.org/10.18535/jmscr/v6i4.90

Journal Of Medical Science And Clinical Research

\title{
Ketamine- The wonder drug in Status Asthmaticus
}

\author{
Authors \\ Dr Gayatri Sakrikar ${ }^{1}$, Dr Rachana Chhabria ${ }^{2}$, Dr Anish Dave ${ }^{3}$ \\ ${ }^{1,3}$ Junior Resident, ${ }^{2}$ Assistant Professor \\ Department of Anaesthesiology, Seth G S Medical College and KEM Hospital, Mumbai
}

\begin{abstract}
A 20 year old male was admitted to intensive care unit with status asthmaticus. Conventional bronchodilator therapy as well as mechanical ventilation failed to improve his lung dynamics. A trial of inj. Ketamine as bolus of $1 \mathrm{mg} / \mathrm{kg}$ followed by infusion of $1 \mathrm{mg} / \mathrm{kg}$ was given. There was improvement in the lung dynamics with decreased peak airway pressures and $\mathrm{PaCO}_{2}$. Patient was weaned and extubated on the fifth day of admission. This case report emphasizes that Ketamine can be a useful drug in life threating severe asthma.
\end{abstract}

\section{Introduction}

Severe asthma is defined as asthma that requires addition of inhaled corticosteroids or addition of second controller (systemic corticosteroid) or which still remains uncontrolled despite the above therapy. ${ }^{(1)}$

We report a case of severe asthma unresponsive to conventional therapy that responded to Ketamine, a phencyclidine derivative commonly used in anaesthesia for its sedative-hypnotic effects.

\section{Case Report}

A 20 year old male with known case of asthma since 10years on inhaled beta agonist and anticholinergics was brought to emergency care unit with severe respiratory distress. Patient was drowsy and not obeying commands. On examination, he had tachycardia, tachypneoa with reduced air entry along with bilateral severe wheeze on auscultation. Immediate arterial blood gas analysis showed type II respiratory failure. The patient was intubated and put on mechanical ventilation.

Conventional therapy with Nebulization (Neb) Levosalbutamol $0.63 \mathrm{mg} \quad 6$ hourly, Neb Budesonide 1mg 8 hourly, Neb Ipratropium bromide $0.5 \mathrm{mg} 6$ hourly were started promptly on arrival. Also Inj. Methylprednisolone $125 \mathrm{mg} 6$ hourly IV was given but did not show any improvement.

Inj Magnesium sulphate and Inj. Aminophylline infusionwere started subsequently due to persistent high airway pressures ranging between 62-69 $\mathrm{cm}$ of $\mathrm{H}_{2} \mathrm{O}$ and $\mathrm{PaCO}_{2}$ of $103 \mathrm{~mm}$ of $\mathrm{Hg}$ on day two. Inspite of mechanical ventilation and above regimen, there was no improvement in the lung dynamics.

After written informed consent, ketamine $1 \mathrm{mg} / \mathrm{kg}$ was administered. Clinical improvement in the form of reduction in the peak airway pressures, 
end tidal $\mathrm{CO}_{2}$ and increased expired tidal volume was observed in initial 30 minutes. Thereafter, infusion of Ketamine started at $1 \mathrm{mg} / \mathrm{kg} / \mathrm{hr}$ and

\begin{tabular}{|l|c|c|c|c|c|c|c|}
\hline Parameter & $\mathbf{P H}$ & $\mathbf{P C O}_{\mathbf{2}}$ & $\mathbf{P O}_{\mathbf{2}}$ & $\mathbf{C H C O}_{\mathbf{3}}$ & $\mathbf{S P O}_{\mathbf{2}}$ & $\mathbf{E T C O}_{\mathbf{2}}$ & $\mathbf{P}_{\text {peak }}$ \\
\hline Before Infusion & 7.13 & 103.6 & 94.1 & 34.2 & 93.9 & 94 & 69 \\
\hline 1 Hour & 7.26 & 78.9 & 85.9 & 35.2 & 94.9 & 88 & 60 \\
\hline 3 Hour & 7.32 & 73.4 & 85.9 & 37.7 & 95.8 & 78 & 55 \\
\hline 6 Hour & 7.41 & 66.9 & 103.9 & 41.5 & 98.2 & 45 & 35 \\
\hline
\end{tabular}

Infusion of ketamine was tapered after 6 hours to $0.5 \mathrm{mg} / \mathrm{kg} / \mathrm{hour}$ as per clinical response like improved air entry and reversal of respiratory acidosis and then stopped after 8 hours. Improvement in the lung compliance and peak airway pressures were noticed along withc learance of endobronchial secretions. No other adverse effect was noted. Patient was extubated on $5^{\text {th }}$ day of admission by the chest intensivist after successful weaning trial. Patient maintained stable haemodynamics throughout his ICU stay.

\section{Discussion}

Ketamine is a bronchial smooth muscle relaxant. It improves pulmonary compliance and increases mucocilliary function. The mechanism by which it produces airway relaxation is still unclear. Several mechanisms has been postulated such as increased catecholamine concentration, inhibition of catecholamine uptake, blockage of voltage gated $\mathrm{Ca}^{+2}$ channels and inhibition of postsynaptic nicotinic and muscarinic receptors ${ }^{(2)}$.

Several clinical trials support use of ketamine for the treatment of refractory bronchospasm in status asthmaticus. It can be used as IV bolus at $0.1 \mathrm{mg} / \mathrm{kg}$ to $2 \mathrm{mg} / \mathrm{kg}$. It can also be used as a continuous infusion at $0.15 \mathrm{mg} / \mathrm{kg} / \mathrm{hr}$ to $2.5 \mathrm{mg} / \mathrm{kg} / \mathrm{hr}$. The duration of infusion ranges from 1 hour to 15 days as per clinical response. ${ }^{(3)}$

Ketamine is relatively safer drug as it protects airway reflexes and has fewer side effects like increased secretions, disorientation in sensory and motor perception and depression.

In this case, long standing treatment with beta agonist and anticholinergics may have resulted in down regulation of the receptors, thus making them unresponsive to conventional treatment. ${ }^{(4)}$ In serial ABGAs were taken along with the monitoring of clinical parameters. such case, a new drug may act by different mechanism producing improvement.

F. Heshmati, et al found similar results with Ketamine use in status asthmaticus patients not responding to conventional therapy. ${ }^{(2)}$ Goyal et al in their review about Ketamine in Status asthmaticus found reduction in peak inspiratory pressures, improved gas exchange, dynamic compliance and minute ventilation in mechanically-ventilated patients with severe bronchospasm after introduction of ketamine. ${ }^{(3)}$

\section{Conclusion}

Ketamine can be used as a bronchodilator in severe asthma refractory to routine medications. It improves lung compliance and obviates need of mechanical ventilation with minimal adverse effects. However its use in every patient should not be emphasised as most of the patients with status asthmaticus respond to conventional management.

\section{References}

1. Chung KF, Wenzel SE, Brozek JL, Bush A, Castro M, Sterk PJ, et al. International ERS/ATS guidelines on definition, evaluation and treatment of severe asthma. Eur Respir J. 2014;43(2):343-73.

2. FARHAD HESHMATI, et al. Use of Ketamine in Severe Status Asthmaticus in Intensive Care Unit. Iranian Journal of Allergy, Asthma and Immunology, [S.1.], p. 175-180, Dec. 2003. ISSN 1735-5249.

3. Goyal S, Agrawal A. Ketamine in status asthmaticus: A review. Indian Journal of Critical Care Medicine: Peer-reviewed, Official Publication of Indian Society of 
Critical Care Medicine. 2013; 17(3):154161. doi:10.4103/0972-5229.117048.

4. Townley RG. Beta-Adrenergic Receptors and Mechanisms in Asthma: The New Long-Acting Beta-Agonists. Allergol Int [Internet]. 1996;45(1):13-22. 